\title{
Efficient Adsorption of Lead Ions from Synthetic Wastewater Using Agrowaste-Based Mixed Biomass (Potato Peels and Banana Peels)
}

\author{
Aamna Ashfaq ${ }^{1,2, *}$, Razyia Nadeem ${ }^{1, *}$, Shamsa Bibi ${ }^{1}$, Umer Rashid ${ }^{3} \mathbb{D}$, Muhammad Asif Hanif ${ }^{1}$, Nazish Jahan ${ }^{1}$, \\ Zeeshan Ashfaq ${ }^{2}$, Zubair Ahmed ${ }^{1}$, Muhammad Adil ${ }^{1}$ and Maleeha Naz ${ }^{1}$
}

1 Department of Chemistry, University of Agriculture, Faisalabad 38040, Pakistan; shamsa.pakistan@gmail.com (S.B.); muhammadasifhanif@gmail.com (M.A.H.); drmuhammadasifhanif@gmail.com (N.J.); zuba1r.ahm3d5@yahoo.com (Z.A.); muhammadadi1507@gmail.com (M.A.); nazmaleeha025@gmail.com (M.N.)

2 Department of Material Sciences, Shandong University, Jinan 250100, China; zee494202@rocketmail.com

3 Institute of Nanoscience and Nanotechnology (ION2), Universiti Putra Malaysia (UPM), Serdang 43400, Malaysia; umer.rashid@upm.edu.my

* Correspondence: amnaashfaq9@yahoo.com (A.A.); raziyaanalyst@yahoo.com (R.N.)

check for updates

Citation: Ashfaq, A.; Nadeem, R.; Bibi, S.; Rashid, U.; Hanif, A.; Jahan, N.; Ashfaq, Z.; Ahmed, Z.; Adil, M.; Naz, M. Efficient Adsorption of Lead Ions from Synthetic Wastewater Using Agrowaste-Based Mixed Biomass (Potato Peels and Banana Peels). Water 2021, 13, 3344. https:// doi.org/10.3390/w13233344

Academic Editor: Laura Bulgariu

Received: 16 September 2021

Accepted: 15 October 2021

Published: 25 November 2021

Publisher's Note: MDPI stays neutral with regard to jurisdictional claims in published maps and institutional affiliations.

Copyright: (c) 2021 by the authors. Licensee MDPI, Basel, Switzerland. This article is an open access article distributed under the terms and conditions of the Creative Commons Attribution (CC BY) license (https:// creativecommons.org/licenses/by/ $4.0 /)$.

\begin{abstract}
The aquatic environment is continuously being polluted by heavy metals released from industrial, domestic, agricultural, and medical applications. It is difficult to remove heavy metals, as they are nonbiodegradable. Heavy metals cause genotoxicity and serious carcinogenic disorders. Various conventional methods have been used for the removal of heavy metals, but these are timeconsuming and not economical, so green methods, being economical, are preferred over conventional methods. Adsorption, being effective, environmentally friendly, and cheap, is often preferred. The present investigation investigated the adsorption efficiency of agrowaste-based biosorbents for removal of $\mathrm{Pb}(\mathrm{II})$ ion from the synthetic wastewater. Mixed biomass of banana peel and potato peels was used to create biosorbents. The biosorbents were characterized in terms of structural and surface morphology by SEM, while functional groups were analyzed by FT-IR and XRD analysis. The adsorption of $\mathrm{Pb}(\mathrm{II})$ was studied by a batch method, and various experimental parameters were studied. Optimum conditions for the removal of lead were $\mathrm{pH}=5$, concentration $=10 \mathrm{ppm}$, adsorbent dosage $=1.0 \mathrm{~g}$, and contact time $=2 \mathrm{~h}$. Kinetic modelling studies showed that the adsorption of $\mathrm{Pb}$ (II) ions followed a pseudo-second-order mechanism, and the Langmuir isotherm model was found to fit well for this study. Highlights: Synthesis of biosorbents (mixed biomass of potato peel and banana peel, biochar, $\mathrm{TiO}_{2}$ nanocomposites). Characterization of prepared biosorbents (SEM, XRD, FT-IR). Optimized parameters ( $\mathrm{pH}$, initial concentration, adsorbent dosage, and contact time) for removal of pollutant.
\end{abstract}

Keywords: biosorption; adsorption; mixed biomass; heavy metal; kinetic study; Freundlich model

\section{Introduction}

Water is a fundamental component of human life. Its chemical properties and dissolving ability are enhanced by its structural polarity and hydrogen bonding. This essential resource is continuously being polluted with various contaminants. Heavy metals are one of the most important threats to our environment. Leathermaking, electroplating, tannin, battery manufacturing, mining, and smelting are major sources of the discharge of heavy metals which contaminate water [1]. Heavy metals are often found in excess levels in ecosystems and are extremely toxic, ranked among highly lethal metals [2]. Among these trace metals, $\mathrm{Cu}^{2+}, \mathrm{Pb}^{2+}, \mathrm{Hg}^{2+}, \mathrm{Zn}^{2+}, \mathrm{Cd}^{2+}, \mathrm{Cr}^{6+}, \mathrm{Ni}^{2+}$, and $\mathrm{As}^{3+}$ have been considered as pollutants in the contaminated water. Small amounts of these metals can greatly injure the human body, affecting the central brain, kidney, and liver. Central nervous system disorders can in turn lead to coma and death. Also, lead poisoning in lower concentrations 
may cause anemia and produce lining on gums. The permitted safety level for $\mathrm{Pb}^{+2}$ content in drinking water is no more than $0.01 \mathrm{mg} / \mathrm{L}[3,4]$. Heavy metals are conventionally treated through ion exchange, precipitation, membrane processes, adsorption with activated carbon oxidation, and reduction [5]. However, these techniques result in the generation of secondary pollutants, incomplete removal of metal ions, high operational cost, low selectivity, high consumption of reagents and energy [6]. Furthermore, it has been reported that some of these techniques are generally incapable of meeting the discharged standard limits for the concentration of heavy metals, with results in the range of $0.1-3 \mathrm{mg} / \mathrm{L}$ [7]. Biosorption of metals to the surface of an adsorbent involves the mechanism of either physical binding (electrostatic or Van der Waals forces) or chemical linkage (covalent or ionic bonding) between the adsorbate and adsorbent. Biosorption is more economical and less effective for health than many of the latest techniques, which is why it has become a focus of attention among researchers [8]. The phenomenon of biosorption depends on the metal and properties of the cell surface. Several researchers have reported the functional groups of biomasses and revealed biosorption mechanisms, including biosorption of metals. The significance of group present in biosorbent for a certain pollutant depends on different factors such as several active sites, the chemical state of those sites, and affinity between sites. Adsorbents must have accessible sites, strong binding with the pollutant, large surface area, and a porous structure to remove contaminants in little time [9]. Many agricultural waste-based adsorbents have been found useful in removing heavy metals from industrial wastewater, such as orange peel [9-11], almond shell [12], chestnut [13], corncobs [14], sugarcane bagasse [15], pomegranate peel [16], peanut shell [17], apricot stone [18], and many others. In this study, we used a 1:1 mixture of banana and potato peels for adsorption of selective heavy metals on a batch scale from wastewater, because these peels are excessively available from local households, canteens, and juice shops. Many active functional groups are present in banana and potato peels; hence, they are effective for the biosorption of heavy metals.

Potato (Solanum tuberosum) peels contain vitamins, starch, nonstarch polysaccharides, protein, acid-soluble/insoluble lignin, lipids, and ash. They have been reported as adsorbents for removal of $\mathrm{Cu}(\mathrm{II})$ and $\mathrm{Cr}(\mathrm{VI})$ [19]; $\mathrm{As}^{3+}$ and $\mathrm{Pb}^{2+}$ [20]; and $\mathrm{Ni}(\mathrm{II}), \mathrm{Cu}(\mathrm{II}), \mathrm{Co}(\mathrm{II})$, $\mathrm{Cd}(\mathrm{II}), \mathrm{Fe}(\mathrm{II}), \mathrm{La}(\mathrm{III})$, and $\mathrm{Pb}(\mathrm{II})$ [21]. Banana (Musa acuminate) peels have an affinity for heavy metal adsorption because of various potential groups such as amino, alkoxy hydroxyl, and carbonyl groups [22] Peels of banana have been reported as adsorbents for $\mathrm{Cr}(\mathrm{VI})$ ions [23], $\mathrm{Pb}$ (II) [24], $\mathrm{Cd}(\mathrm{II})$ [25], Fe(II) ions [26], and $\mathrm{Cr}(\mathrm{VI})$ and $\mathrm{Mn}$ (II) [27]. In the present research, a mixture of both banana and potato peels was used for adsorption of $\mathrm{Pb}$ (II) on the batch scale, and different operational parameters were investigated.

Biochar is a material that contains an abundant amount of carbon and is gained from biomass. It is interesting because it has availability in excess, wide surface area, a large amount of functional groups present on the surface area, a possible conversion process, and ecofriendly behavior [28]. Synthesis of functional biochar of enhanced surface characteristics has drawn great attention but is a great challenge for the development of adsorption processes. Two main factors that greatly affect biochar's surface properties are biomass type and carbonization [29]. In the present study, banana peel and potato peel were used as agrowaste that was further pyrolyzed into biochar.

Nanotechnologies are a group of methods for treating matter; their main focus is to obtain materials with enhanced characteristics. Nanoparticles play an essential role in many applications. In particular, there have been many studies related to nanoparticles of titanium dioxide. Titanium dioxide nanoparticles have been synthesized and studied since the 20th century. They have been considered for uses including air purification, and specifically the reduction of sulfur oxides, nitrogen oxides, carbon monoxide, aromatic hydrocarbons and polycondensed aromatic hydrocarbons, and volatile organic compounds emitted from plasters and paints in adjacent environments [30].

Nanocomposite materials have an exceptionally large surface-to-volume ratio because of their nanosize and the activity of their surfaces. By charging nanoparticles to the 
appropriate matrix, the properties of the obtained polymer nanocomposites are improved, e.g., thermal stability, mechanical properties, and electrical conductivity [31,32]. Therefore, nanomaterials have played a supporting role in improving the mechanical properties of barrier food packaging materials and developing structures for active and smart packaging applications. Bionanocomposites are a particular type of material distinguished by having one very fine dimension of at most a few nanometers. Moreover, nanocomposites have gained a great deal of attention in engineering and polymer science [33].

The present work aimed to compare the adsorption capacity $(\mathrm{mg} / \mathrm{g}$ ) of mixed biomass of potato peel and banana peel, the biochar of the prepared biomass, and $\mathrm{TiO}_{2}$ /agrowastebased biochar nanocomposites (which were made by using Psidium guajava leaf extract for preparation of nanoparticles and potato and banana peel as a matrix) and investigate the factors affecting adsorption capacity.

Parameters including contact time, $\mathrm{pH}$, initial concentration, and adsorbent dosage were studied. The kinetic data and equilibrium of biosorption were tested using isotherm models (Langmuir and Freundlich) and two kinetic models (pseudo-first-order and pseudosecond-order).

\section{Material and Methods}

\subsection{Pollutant}

The synthetic polluted solutions of desired concentrations of $\mathrm{Pb}(\mathrm{II})$ were prepared by dissolving $\mathrm{Pb}\left(\mathrm{NO}_{3}\right)_{2}$ in deionized water. The reagents used were of analytical grade. A total of $1.5984 \mathrm{~g}$ of $\mathrm{Pb}\left(\mathrm{NO}_{3}\right)_{2}$ was dissolved in $1000 \mathrm{~mL}$ of deionized water to give a concentration of $1000 \mathrm{mg} / \mathrm{L}$ of $\mathrm{Pb}^{2+}$ ion in solution. From the $1000 \mathrm{mg} / \mathrm{L}$ stock solution, $10 \mathrm{~mL}$ was diluted to $100 \mathrm{~mL}$, which gave a $100 \mathrm{mg} / \mathrm{L}$ (100 ppm) working solution. Experimental solutions of desired concentrations were then obtained by successive dilutions. The initial $\mathrm{pH}$ measurements were conducted with a $\mathrm{pH}$ instrument and were calibrated using buffer solutions with known $\mathrm{pH}$ values. The $\mathrm{pH}$ of the synthetic contaminated water was modified by the addition of dilute $\mathrm{NaOH}$ and $\mathrm{HCl}$ solutions.

\subsection{Biosorbent}

Three biosorbents were made for comparative study.

Peels of Musa acuminata and Solanum tuberosum were collected from a local market and household waste. They were washed properly and rinsed with deionized water to remove all dust particles and then dried in sunlight for a week. The dried peels were then ground to fine powder, and the agrowaste was further ground to a particle size of $\sim 0.5 \mathrm{~mm}$. The resulting particles were stored in hermetic plastic bags for further use [34].

Prepared biomass was pyrolyzed at $550{ }^{\circ} \mathrm{C}$ for $2 \mathrm{~h}$ at a heating rate of $2{ }^{\circ} \mathrm{C} \mathrm{min}-1$ [35]

To prepare $\mathrm{TiO}_{2}$ nanocomposites, first, titanium dioxide nanoparticles were prepared by a green synthesis method using titanium tetraisopropoxide (TTIP) and extract of guava leaves [36]. Fifty milligrams of biochar was sonicated with ethanol, and then titanium dioxide nanoparticles were added into the dispersed biochar. The developed dispersed mixture was ultrasonicated for $3 \mathrm{~h}$, followed by drying at moderate conditions to remove the solvent. After drying, the prepared nanocomposite was deposited on a petri dish and subjected to microwave irradiation for 2 min to give better exfoliation [37].

\section{Characterization of Adsorbent}

The surface functional groups on the biosorbent sample were identified by FT-IR spectrophotometry, while SEM was used to identify the surface morphology and X-ray diffraction (XRD) was used to determine the crystalline structure and orientation of the biosorbent.

\subsection{FT-IR Spectroscopy}

The molecular fingerprint of the materials was examined through Fourier transform infrared spectroscopy, which allows close examination of a sample's chemical composition. 


\subsubsection{FT-IR Analysis of $\mathrm{TiO}_{2} \mathrm{NPs}$}

FT-IR spectra of $\mathrm{TiO}_{2}$ are shown in Figure 1a. Peaks were present at 498 to $550 \mathrm{~cm}^{-1}$; these peaks correspond to $\mathrm{O}-\mathrm{Ti}-\mathrm{O}$ and $\mathrm{Ti}-\mathrm{O}$ bending vibrations and are present in the fingerprint region of the spectra. No peaks were observed in the functional group because there was no functional group present in the prepared sample. A broad peak present at $1621.69 \mathrm{~cm}^{-1}$ showed a Ti-OH stretching vibration [38].
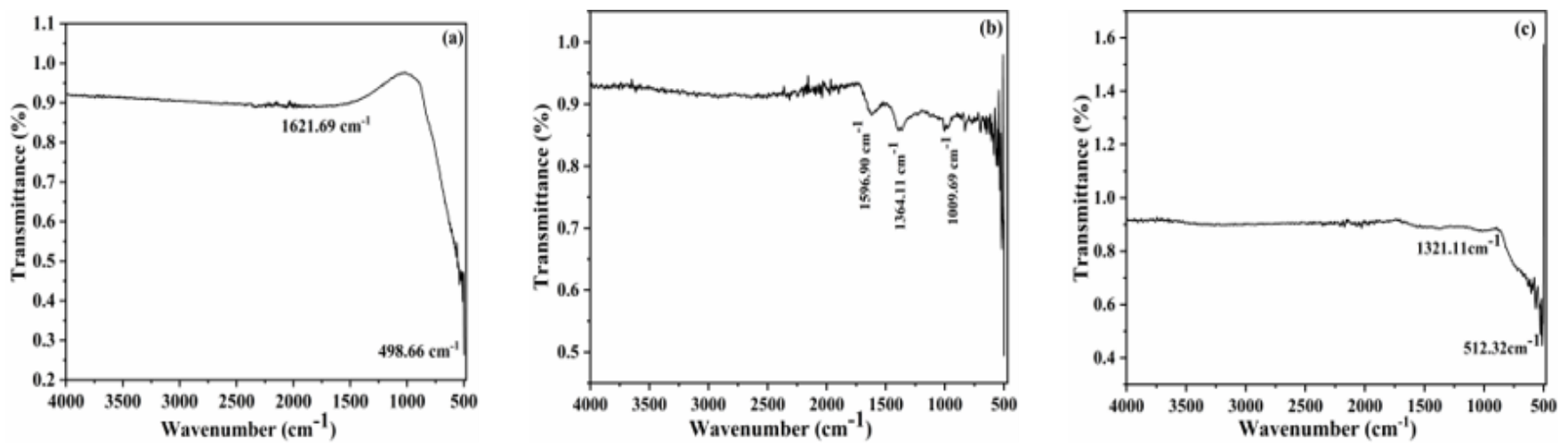

Figure 1. FT-IR spectra of (a) $\mathrm{TiO}_{2} \mathrm{NP}$; (b) biochar; (c) $\mathrm{TiO}_{2}$ nanocomposite.

\subsubsection{FT-IR Analysis of Biochar}

Spectra shown in Figure $1 \mathrm{~b}$ confirmed the presence of abundant surface functional groups such as carboxyl and hydroxyl, which greatly enhanced the adsorption performance. A conjugated (Hibbert's) ketone $\mathrm{C}=\mathrm{O}$ band at $1699 \mathrm{~cm}^{-1}$ might have been derived from lignin demethylation of an aromatic methoxy group. The absorption bands at $1704-1612 \mathrm{~cm}^{-1}$ were assigned to $\mathrm{C}-\mathrm{O} / \mathrm{C}=\mathrm{O}$ stretching vibrations of aromatic rings of lignin, while those at $2925-1375 \mathrm{~cm}^{-1}$ were assigned to the bending vibration of $\mathrm{CH}_{3}$ and $\mathrm{CH}_{2}[39,40]$.

\subsubsection{FT-IR Analysis of $\mathrm{TiO}_{2} \mathrm{NCs}$}

After combining biochar with $\mathrm{TiO}_{2} \mathrm{NPs}$, an increase in the relative peak intensity at about $512.32 \mathrm{~cm}^{-1}$ was observed for $\mathrm{TiO}_{2} \mathrm{NCs}$, which is often used for confirmation of vibrations of Ti-O. The bands at $2925-1375 \mathrm{~cm}^{-1}$ correspond to the bending vibration of $\mathrm{CH}_{3}$ and $\mathrm{CH}_{2}$. Spectra are shown in Figure 1c.

\subsection{Scanning Electron Microscopy (SEM) Analysis}

Biocomposites are particularly sensitive to imaging techniques that are carried out to describe them, as they are deformable and sensitive materials. SEM micrographs of bare and lead-loaded mixed biomass, biochar, and $\mathrm{TiO}_{2} \mathrm{NC}$ are shown in Figure 2. Figure 2a-c shows the bulky and smooth morphology of the bare biosorbents. However, Figure $2 \mathrm{~d}-\mathrm{f}$ indicates the presence of fine spherical nanostructures. By the simple comparison of the SEM images of the loaded and unloaded biosorbents, it is clearly shown that $\mathrm{Pb}$ (II) was adsorbed on the surface of biosorbents.

\subsection{XRD Analysis of $\mathrm{TiO}_{2} \mathrm{NP}$}

The results of X-ray diffraction of $\mathrm{TiO}_{2} \mathrm{NP}$ are given in Figure 3. Strong diffraction peaks were present at 2 theta values of $25.19^{\circ}, 36.82^{\circ}, 37.65^{\circ}, 38.44^{\circ}, 47.92^{\circ}, 53.73^{\circ}, 54.93^{\circ}$, and $61.96^{\circ}$; they were associated with planes (011), (013), (004), (112), (020), (015), (121), and (024). These peaks are characteristic of $\mathrm{TiO}_{2}$. The $\mathrm{X}$-ray diffraction pattern at $25.19^{\circ}$ and $36.82^{\circ}$ indicated that all peaks observed for $\mathrm{TiO}_{2}$ were under the standard spectrum (JCPDS no.: 88-1175 and 84-1286). This diffraction pattern shows that diffraction peak intensity 
increased with increasing particle size [41]. The average particle size was calculated by using the Scherrer formula, which is given as:

$$
D=K \frac{\lambda}{\beta \cos \theta}
$$

where $K$ is a constant, $\lambda$ is the wavelength of radiation, and $\beta$ is the full-width half maximum. The average particle size of $\mathrm{TiO}_{2}$ was found to be $11.73 \mathrm{~nm}$. The lattice parameters were $\mathrm{a}=3.78 \AA$ and $\mathrm{c}=9.53 \AA$, and the system was tetragonal. The XRD pattern of $\mathrm{TiO}_{2} \mathrm{NPs}$ is shown in Figure 3.

(a)

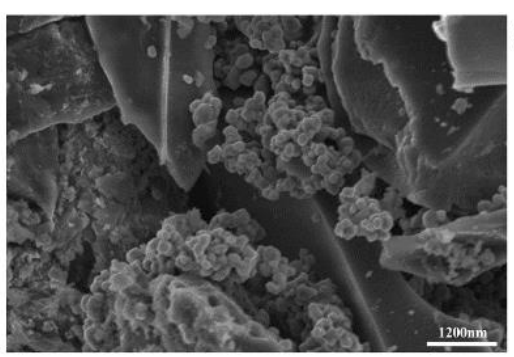

(d)

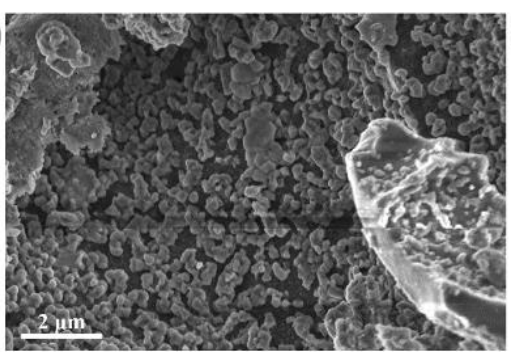

(b)

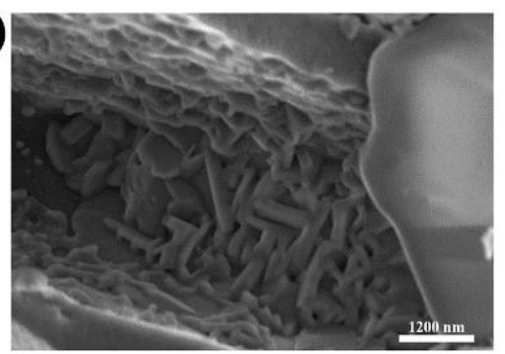

(e)

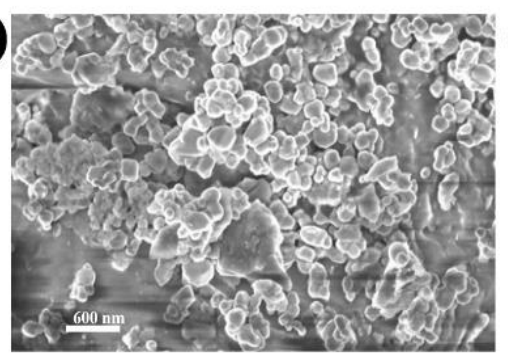

(c)

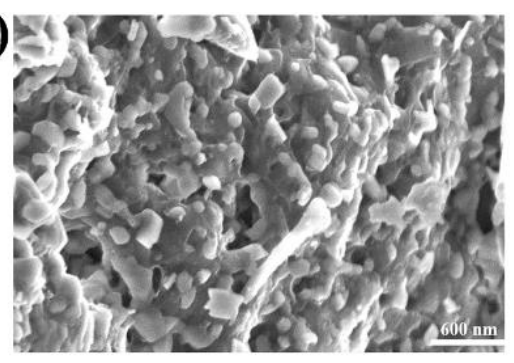

(f)

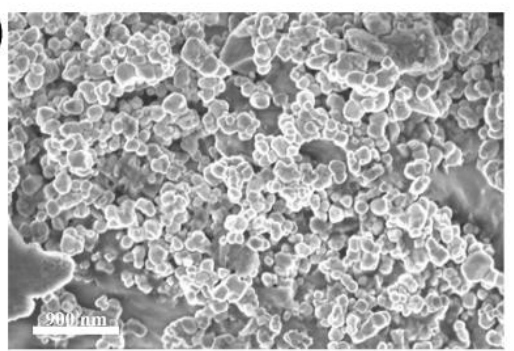

Figure 2. SEM micrographs: (a) bare biomass; (b) bare biochar; (c) bare $\mathrm{TiO}_{2} \mathrm{NCs}$; (d) lead-loaded biomass; (e) lead-loaded biochar; (f) lead-loaded $\mathrm{TiO}_{2} \mathrm{NCs}$.

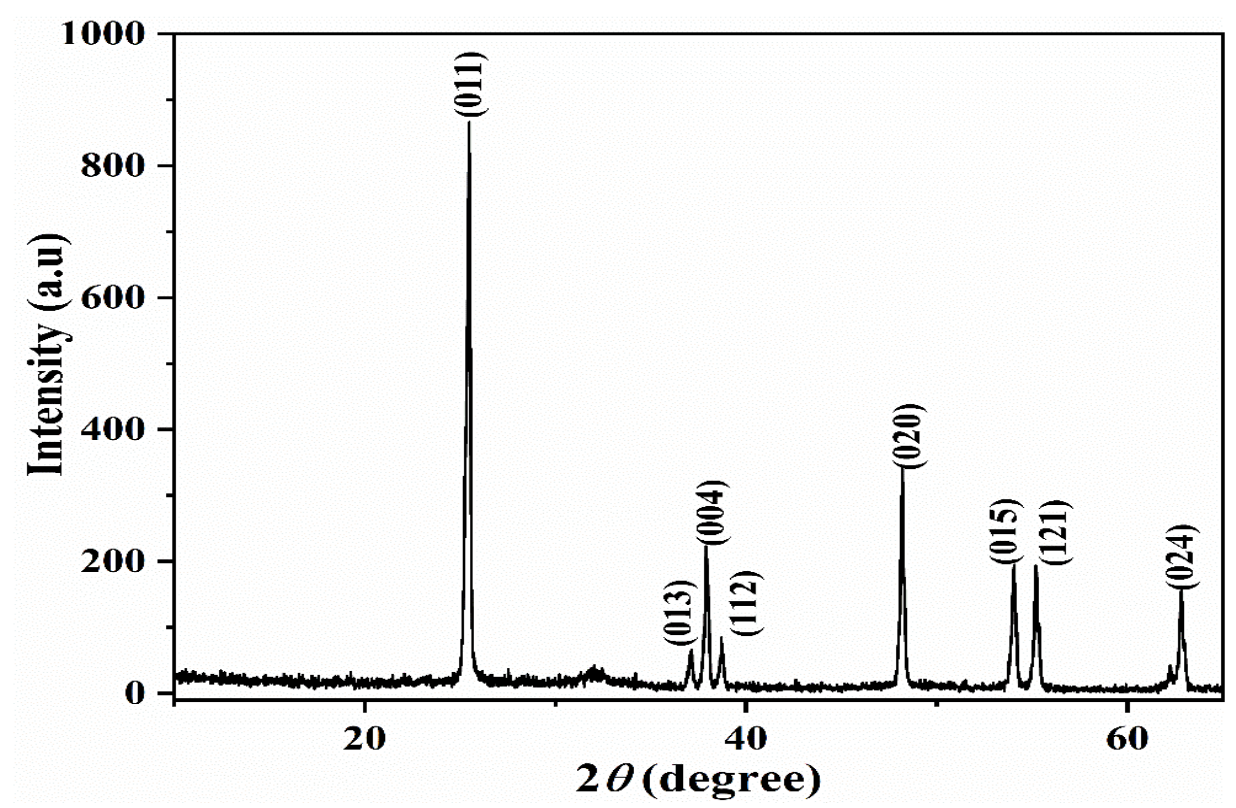

Figure 3. XRD pattern of $\mathrm{TiO}_{2} \mathrm{NPs}$.

\subsection{UV Analysis of $\mathrm{TiO}_{2}$ Nanoparticles $\left(\mathrm{TiO}_{2} \mathrm{NP}\right)$}

Synthesis of nanoparticles was confirmed by a UV/visible spectroscopy peak of maximum absorption observed between 290 and $310 \mathrm{~nm}$. A maximum adsorption peak 
was observed at $295 \mathrm{~nm}$. The results agreed with already reported literature, where the peak was observed at $310 \mathrm{~nm}$ [42]. The UV spectrum is shown in Figure 4.

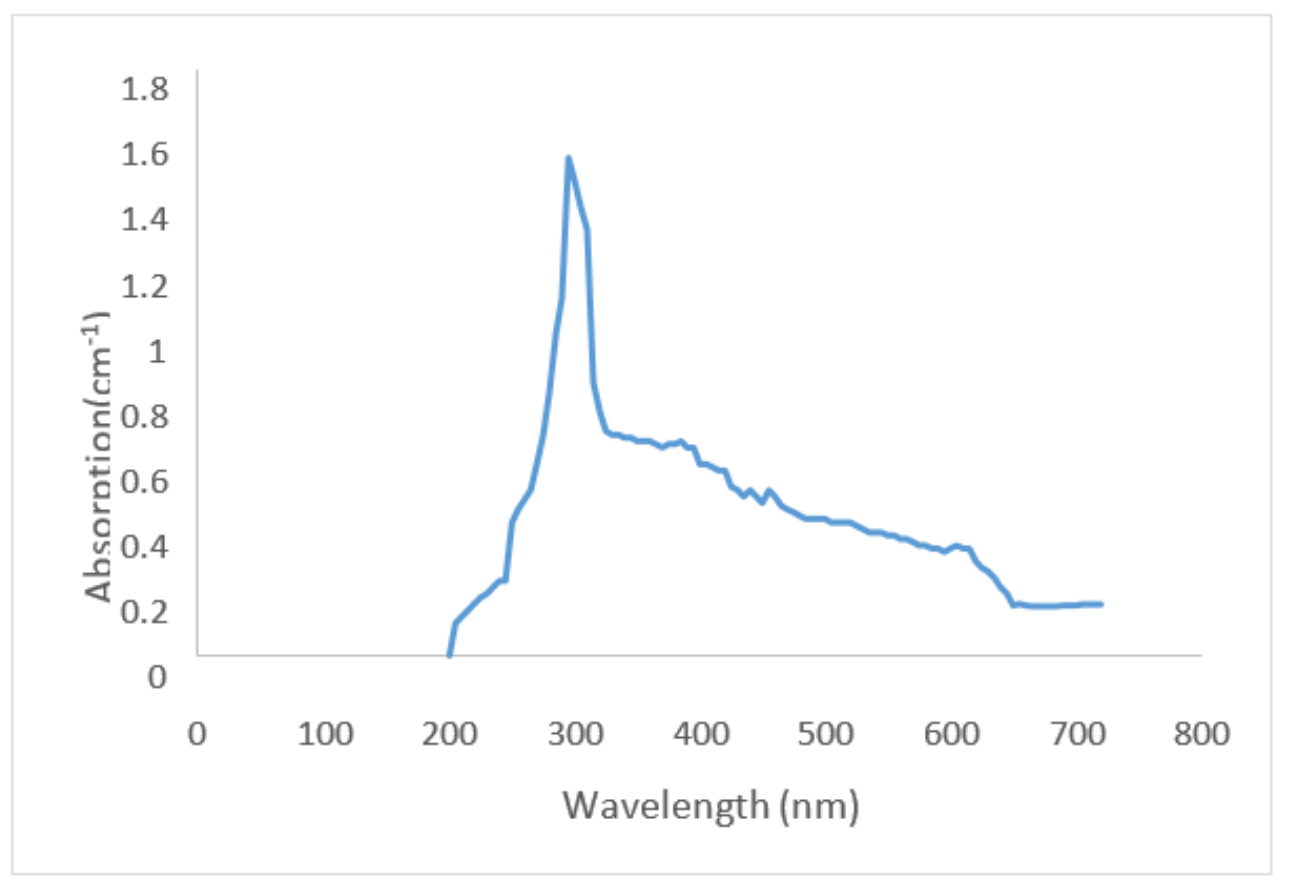

Figure 4. UV spectra of $\mathrm{TiO}_{2} \mathrm{NPs}$.

\section{Results and Discussion}

A batch adsorption experiment was conducted to optimize the parameters. The efficiency of lead removal was examined by different parameters. The amount of lead removal was calculated using the following formula:

$$
q=\frac{\left(C_{i}-C_{e}\right) v}{C_{i}} \times m
$$

where $C_{i}$ and $C_{e}$ are the lead concentrations $(\mathrm{mg} / \mathrm{L})$ initially and at a given time, $V$ is the volume of solution $(\mathrm{L})$, and $m$ is the mass of the adsorbent $(\mathrm{g})$.

\subsection{Effect of $\mathrm{pH}$ on Lead Adsorption}

$\mathrm{pH}$ affects the process of adsorption; indeed, it is the most important parameter. Adsorption varies because of change in the $\mathrm{pH}$ of a solution. This variation in adsorption results in variation of uptake capacity of lead, as the $\mathrm{pH}$ of the solution may affect the functional groups present on the surface of adsorbents. Charges on the surface of adsorbents were regulated by the $\mathrm{pH}$ of the solution through deprotonation and protonation of functional groups present on the surface.

In the solution, removal efficiency generally decreased as $\mathrm{pH}$ increased, and maximum removal efficiency for lead was observed at a $\mathrm{pH}$ of 5 . Said maximum removal efficiency of lead was observed to be $91.4634 \mathrm{mg} / \mathrm{g}$ with $\mathrm{TiO}_{2} \mathrm{NCs}$. The maximum uptake in $\mathrm{mg} / \mathrm{g}$ of lead for each adsorbent was as follows: $91.4634\left(\mathrm{TiO}_{2} \mathrm{NCs}\right)>85.9146$ (biochar) $>79.2073$ (biomass).

Different adsorbents showed a comparable binding pattern for lead. The adsorbent surface became negatively charged. This was responsible for electrostatic interaction between the adsorbent surface and the metals, which resulted in efficient removal of heavy metals.

The effect of $\mathrm{pH}$ on the adsorption of lead by biomass of banana peel and potato peel, biochar, and $\mathrm{TiO}_{2} \mathrm{NCs}$ was investigated. The $\mathrm{pH}$ range of 1.0-10 was studied to evaluate 
the optimum $\mathrm{pH}$, while other variables were kept constant (amount of adsorbent $=0.1 \mathrm{~g}$, temperature $=35^{\circ} \mathrm{C}$, shaking speed $=120 \mathrm{rpm}$, and concentration $=100 \mathrm{ppm}$ ). The effect of $\mathrm{pH}$ on adsorption of lead by using biomass, biochar, and $\mathrm{TiO}_{2} \mathrm{NC}$ is shown in Figure 5 a.
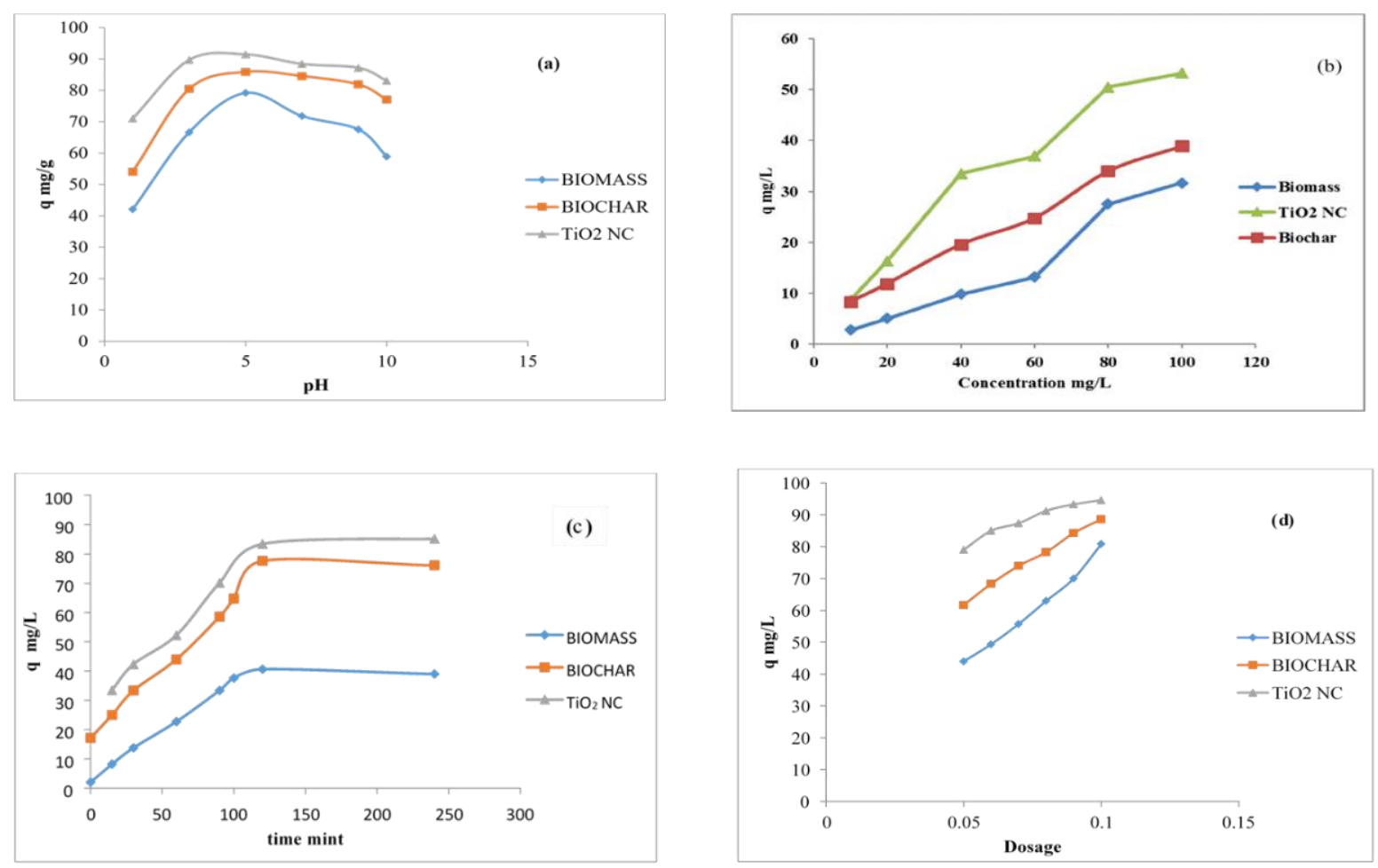

Figure 5. (a) Effect of $\mathrm{pH}$; (b) effect of concentration; (c) effect of contact time; (d) effect of adsorbent dosage.

\subsection{Effect of Initial Concentration on Lead Adsorption}

Initial concentration is responsible for overcoming all barriers for mass transfer of particles between the solid and liquid phases. The effect of initial concentration on adsorption for the elimination of lead from liquid solution was evaluated in this study using different adsorbents. The solution concentration of lead was varied from 10 to $100 \mathrm{ppm}$. A pH of 5 was maintained for lead solution. Adsorbent dosage was $0.1 \mathrm{~g}$. The results illustrated that the percentage of lead removed decreased as initial concentration increased [43]. As the amount of adsorbent was the same, the competition was negligible at low concentrations but became prominent with the increase in concentration of adsorbate molecules. In simple words, the number of adsorption sites was limited at high solution concentrations, which hindered the further uptake, and hence, diffusion, and with it the percentage of lead removed, decreased.

The maximum removal efficiency of lead, $90.742 \mathrm{mg} / \mathrm{g}$, was observed at $10 \mathrm{ppm}$ with $\mathrm{TiO}_{2}$ NCs. The maximum uptake in $\mathrm{mg} / \mathrm{g}$ of lead at $10 \mathrm{ppm}$ for each adsorbent was as follows: 90.742 ( $\left.\mathrm{TiO}_{2} \mathrm{NCs}\right)>83.2797$ (biochar) $>73.578$ (biomass). It was demonstrated that percentage of removal increased with the decrease in initial concentration. This pattern might be due to the reason that at low initial concentration, there was a large number of active sites and adsorbate molecules that bound lead ions independently, and so the process of adsorption was fast. However, when the concentration was high, there were fewer binder sites as compared to the number of adsorbate molecules. The process of adsorption depends on the active sites present on the surface of the adsorbent. There was a limited number of active sites for the adsorption of lead on each adsorbate; the active sites became saturated at a certain concentration, and hence the percentage of removal decreased once concentration increased to the saturation point and there were no more 
active sites for the loading of heavy metals [44]. The effect of initial concentration on the adsorption of lead with biomass, biochar, and $\mathrm{TiO}_{2} \mathrm{NCs}$ is shown in Figure $5 b$.

\subsection{Effect of Contact Time on Lead Adsorption}

Contact time is a vital factor in the process of adsorption. Over time, more interaction occurs between adsorbent and adsorbate molecules, and so the adsorption rate is increased. In the present work, the effect of contact time on the adsorption of lead with comparable biosorbents was studied with a distinct time interval over a range from 15 to $120 \mathrm{~min}$. The concentration of heavy metals solution was kept at $100 \mathrm{ppm}$. The percentage of lead removed increased as time increased until equilibrium was achieved. Different studies have revealed that most of heavy metals are removed by the adsorption process within two hours, as equilibrium is attained at $120 \mathrm{~min}$.

At the start of the process, there was a higher concentration gradient between the biosorbents and lead ions that sped up the process. When the adsorption process started, a large number of binding sites were available. As time passed, functional groups present on the surface of the adsorbent took part in process of adsorption of heavy metals until equilibrium was achieved. The percentage of removal increased with an increase in contact time but becomes constant after attaining equilibrium. After equilibrium, the adsorption process may slow down because of the contribution of other processes, e.g., complexation, saturation of binding sites, and microprecipitation. As equilibrium was achieved, no more lead ions were further adsorbed by increasing contact time because there were no vacant sites available. Therefore, contact time for the adsorption process was optimized. The adsorption process was rapid within the first $2 \mathrm{~h}$ because of the availability of empty adsorption sites at the initial stage. As time passed, adsorption sites became saturated, and equilibrium was attained.

The uptake of both adsorbates increased rapidly at the beginning. The maximum adsorption capacity of more than $80 \%$ was achieved within $2 \mathrm{~h}$. This behavior may have been due to the large number of vacant sites available at the beginning. Adsorption then slowed down until the attainment of equilibrium [45]. The effect of contact time on adsorption of lead by using biomass, biochar, and $\mathrm{TiO}_{2} \mathrm{NCs}$ is shown in Figure 5c. The maximum uptake in $\mathrm{mg} / \mathrm{g}$ of lead for each adsorbent was as follows: $89.2621\left(\mathrm{TiO}_{2} \mathrm{NCs}\right)>83.8276$ (biochar) $>78.963$ (biomass).

\subsection{Effect of Adsorbent Dosage on Lead Adsorption}

Lead adsorption efficiency as a function of adsorbent dosage was studied. The adsorbent dosage was kept in between 0.05 and $0.1 \mathrm{~g}$, while other studied parameters $(\mathrm{pH}$, contact time, and initial ion concentration) were kept optimum, the temperature was maintained at $25^{\circ} \mathrm{C}$, and the agitation speed was kept at $200 \mathrm{rpm}$. The removal efficiency increased as the dosage of biosorbents was increased. This was expected, because more binding sites were available for lead ions when the dose of biosorbents was high. These observations described that lead adsorption in the wastewater is related to available binding sites. Adsorbents with more surface area were more efficient for removing lead, as they had more binding sites. Moreover, at precise adsorbent dosage, an adsorption peak was seen.

It was observed that the percentage of lead removed increased with the dosage of absorbent. Maximum removal was achieved when $0.1 \mathrm{~g}$ of absorbent was used for adsorption in $100 \mathrm{ppm}$ solution of lead. The mechanism of composite adsorption may be due to Van der Waals forces between the surface of the adsorbent and the heavy metals or to electrostatic attraction between the charged surface of the adsorbent and the heavy metals.

The maximum removal efficiency of lead was observed at $93.506 \mathrm{mg} / \mathrm{g}$ with $\mathrm{TiO}_{2}$ NCs. Maximum uptake in $\mathrm{mg} / \mathrm{g}$ of lead for each adsorbent was as follows: 93.506 $\left(\mathrm{TiO}_{2} \mathrm{NCs}\right)>88.621$ (biochar) $>80.876$ (biomass). 
The effect of adsorbent dosage on the adsorption of lead by using biomass, biochar, and $\mathrm{TiO}_{2} \mathrm{NCs}$ is shown in Figure 5d.

\section{Comparison among Different Adsorbents}

The efficiency of the three adsorbents at removing lead from liquid solution was shown in the order of $\mathrm{TiO}_{2} \mathrm{NCs}>$ biochar $>$ biomass. A comparison of the uptake capacity of the three adsorbents is shown in Figure 6.

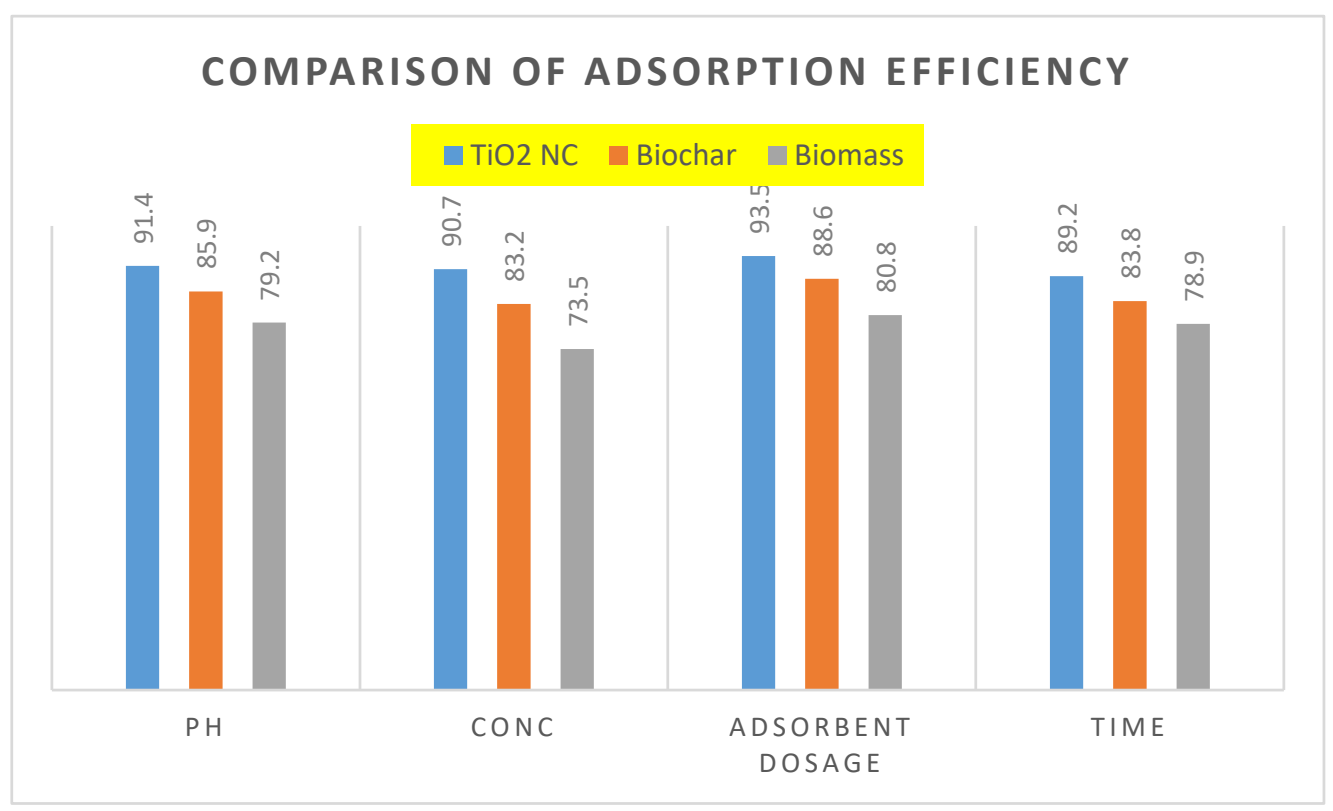

Figure 6. Comparison of adsorption efficiency by adsorbents.

The uptake capacity of prepared biosorbents can also be compared with some reported biosorbents from the literature. A list of some reported agrowaste with the potential to be applied as biosorbents to remove heavy metals from aqueous solutions is presented in Table 1 that can also be compared with the results of the present work.

Table 1. List of reported agrowaste with the potential to be applied as biosorbents to remove heavy metals from aqueous solutions.

\begin{tabular}{ccc}
\hline Adsorbents & Heavy Metals & $\begin{array}{c}\text { Maximum Adsorption } \\
\text { Capacity (m mol } \mathbf{~ g}^{\mathbf{- 1}} \mathbf{)}\end{array}$ \\
\hline Olive waste & $\mathrm{Cd}$ & $0.0655[46]$ \\
\hline Orange peel & $\mathrm{Cd}$ & $0.335[42]$ \\
\hline Orange bark & $\mathrm{Cd}$ & $0.3101[46]$ \\
\hline Rice hull & $\mathrm{Ni}, \mathrm{Cd}, \mathrm{Cu}, \mathrm{Zn}, \mathrm{Pb}$ & $0.085,0.125,0.93,0.17,0.2[47]$ \\
\hline Yellow passion-fruit shell & $\mathrm{Cr}$ & $0.732-1.637[48]$ \\
\hline Sugar beet pulp (Beta vulgaris) & $\mathrm{Cu}, \mathrm{Zn}$ & $0.309,0.356[49,50]$ \\
\hline Carrot residues & $\mathrm{Cu}$ & $0.937[51]$ \\
\hline Grapefruit peel & $\mathrm{Cd}$ & $0.24[52]$ \\
\hline Lemon peel & $\mathrm{Cd}, \mathrm{Mn}, \mathrm{Pb}$ & $0.46,0.43,0.869[53]$ \\
\hline Lemon resin & $\mathrm{Mn}, \mathrm{Pb}$ & $0.429,0.869[53]$ \\
\hline
\end{tabular}




\section{Adsorption Kinetics}

To evaluate the potential rate-controlling step and kinetic mechanism of $\mathrm{Pb}$ (II) biosorption on biomass, biochar, and $\mathrm{TiO}_{2}$ nanocomposites, the pseudo-first-order equation of Laguerre and pseudo-second-order equation of Ho and McKay [54] were investigated. The pseudo-first-order model depends only on the several adsorbate molecules present in an aqueous solution at a definite time. However, the pseudo-second-order model describes that lead ions are present in said aqueous solution as well as the many free active sites present on the surface of the adsorbent.

\subsection{Pseudo-First-Order Model}

The equation of the pseudo-first-order regression model for adsorption was stated as follows:

$$
\log (q e-q t)=\log (q e)-\left(\frac{k 1}{0.2303}\right) t
$$

where $q e(\mathrm{mg} / \mathrm{g})$ is the amount of lead; $q t(\mathrm{mg} / \mathrm{g})$ is the amount of lead that is adsorbed on the biomass at equilibrium state, $\mathrm{t}$ is the time to achieve equilibrium, and $k 1\left(\mathrm{~min}^{-1}\right)$ represents the rate constant for the pseudo-first-order reaction equation. The pseudo-firstorder regression model presumes that the rate of adsorption and the unoccupied sites of lead are proportional to each other. The intercept and slopes of the plot of the graph between the values of $\log (q e-q)$ time $(t)$ were used for the calculation of the pseudo-firstorder rate constant $\mathrm{k} 1$ and the capacity for the equilibrium adsorption. On comparison between the pseudo-first-order and pseudo-second-order models, it was found that the value of $\mathrm{R}^{2}$ for the former was less than that of the latter, so the pseudo-first-order model was not well fitted.

Relatively lower $\mathrm{R}^{2}$ values were obtained for the pseudo-first-order model for lead: 0.9638 for biomass, 0.8477 for biochar, and 0.961 for nanocomposite. The theoretically calculated $q e(\mathrm{mg} / \mathrm{g})$ did not agree well with experimentally calculated $q^{\exp }$. The value of the correlation coefficient was lower than 1 and most often equal to 0.8 . This proved that it was not precise to use this model to conclude the adsorption kinetics of lead by the adsorbents biomass, biochar, and $\mathrm{TiO}_{2}$ nanocomposite.

\subsection{Pseudo-Second-Order Model}

The data of adsorption kinetics were again studied by a pseudo-second-order kinetic model, which presumes that sorption rate depends on adsorption capacity, i.e., that the square of the unoccupied sites is proportional to the sorption rate. It is shown as:

$$
\frac{t}{q}=\frac{1}{k 2 q e 2}+\frac{t}{q e}
$$

where $k 2$ is the equilibrium rate constant $(\mathrm{g} / \mathrm{mg} / \mathrm{min})$. The slopes and intercepts of plots of $t / q$ versus $t$ were used to calculate the pseudo-second-order rate constant $k 2$ and $q e$.

Comparison between the pseudo-first- and -second regression models in regard to the kinetic parameters revealed that lead adsorption on the biomass of potato peel and banana peel, biochar, and $\mathrm{TiO}_{2}$ nanocomposites was better fitted with pseudo-second-order kinetics than pseudo-first-order. The qe value obtained from the pseudo-second-order model was close to conformation with the experimental data, while the value of qe evaluated from contrasting kinetic models did not comply with the experimental value. This shows that the pseudo-first-order model was not satisfactory to explain the mechanism of $\mathrm{Pb}$ (II) biosorption. Evaluation of kinetic data showed that $R^{2}$ values for the pseudo-first- and -second-order models were high ( $>0.96)$ but $q^{\text {cal }}$ did not match $q^{\text {exp }}$ to a great extent [55]. Comparison of the values obtained from psudo first order and pseudo second order given in Table 2 and their graphical representation is in Figure 7a,b. 
Table 2. Comparison of pseudo-first- and -second-order models.

\begin{tabular}{|c|c|c|c|c|c|c|c|c|}
\hline \multirow{3}{*}{ Adsorbate } & \multirow{3}{*}{ Adsorbents } & \multicolumn{2}{|c|}{ Pseudo-First-Order } & \multicolumn{5}{|c|}{ Pseudo-Second-Order } \\
\hline & & $q_{e}$ & K1ad & ? & $q^{\exp }$ & $q_{e}$ & K2ad & \\
\hline & & $(\mathrm{mg} / \mathrm{g})$ & $\left(\min ^{-1}\right)$ & $\mathbf{R}^{2}$ & $(\mathrm{mg} / \mathrm{g})$ & $(\mathrm{mg} / \mathrm{g})$ & (mg/gmin) & $\mathbf{R}^{2}$ \\
\hline \multirow{3}{*}{ Lead } & Biomass & 14.561 & -0.004 & 0.963 & 51.671 & 56.497 & 0.003 & 0.9863 \\
\hline & Biochar & 32.055 & -0.0053 & 0.847 & 68.237 & 70.921 & 4.426 & 0.9878 \\
\hline & $\mathrm{TiO}_{2} \mathrm{NC}$ & 21.892 & -0.005 & 0.961 & 76.751 & 82.644 & 0.0025 & 0.9949 \\
\hline
\end{tabular}
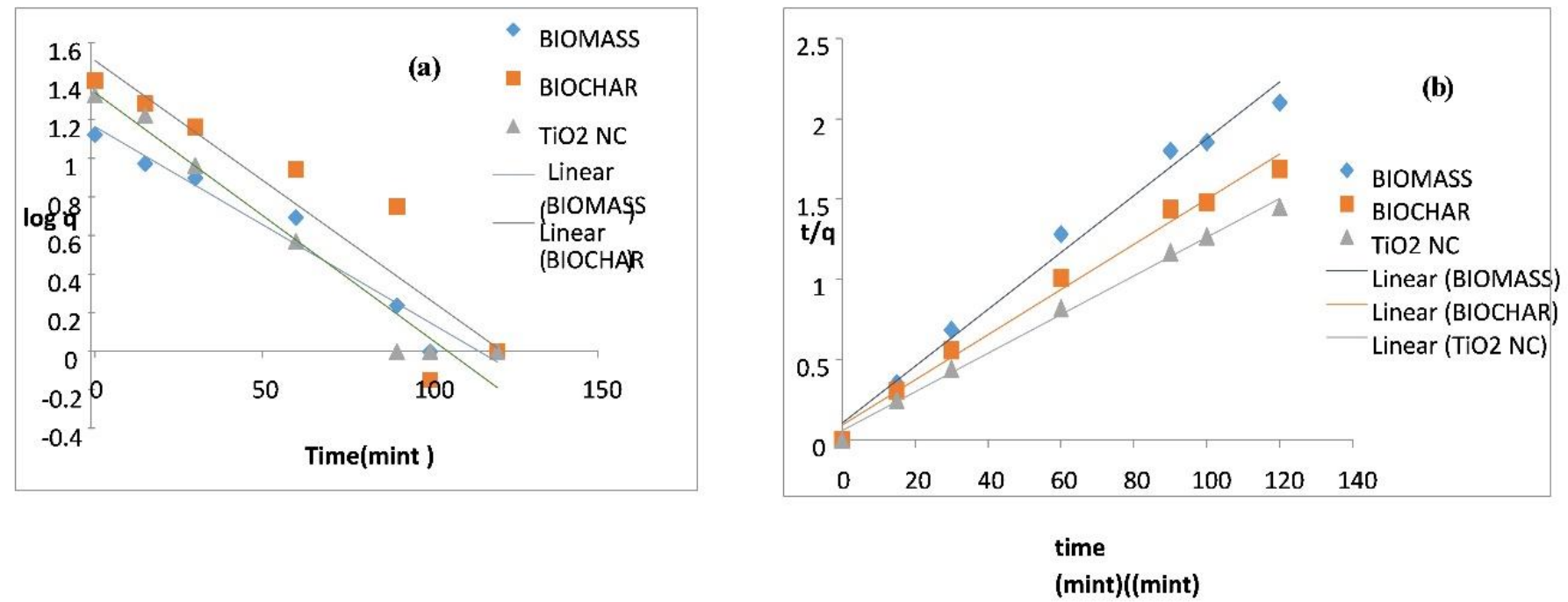

Figure 7. (a) Pseudo-first-order graph; (b) pseudo-second-order graph.

\section{Equilibrium Modelling}

The adsorption isotherms of lead from concentrations of 10 to $100 \mathrm{ppm}$ were studied with a fixed $\mathrm{pH}$ of 5 and an adsorbent dose of $0.1 \mathrm{~g}$. Freundlich and Langmuir adsorption isotherms were used to define the relationship between the adsorbent and adsorbate molecules in aqueous solution. When there was a changing balance in adsorbate concentration in a large volume of solution with that of boundary, sorption equilibrium was established. To develop the equilibrium data, the primary concentration of lead changed. The quantity of adsorbent was kept constant. To obtain equilibrium data, the initial concentration of lead was changed, whereas the number of biosorbents was kept constant. A contact time of $24 \mathrm{~h}$ was used to ensure the equilibrium condition of sorption.

\subsection{Langmuir Isotherm}

Generally, the Langmuir isotherm equation is written as:

$$
\frac{C_{i}}{q e}=\frac{1}{q \max }+\frac{1}{b q \max } C_{e}
$$

where

$C_{e}$ is equilibrium concentration, $q e$ is equilibrium adsorption capacity, $b$ is slope, and $1 /$ qmax is the intercept obtained from the regression equation.

The Langmuir isotherm revealed that the surfaces of the biosorbent and lead had equal sites with the same energy. According to this model, adsorbate molecules do not interact with each other, only with the site. Adsorption is restricted to a monolayer. It is assumed that once a lead ion adsorbs with a site, no more adsorption occurs, and when equilibrium is achieved, a monolayer appears [56]. 
The linear equation of the Langmuir isotherm is written as:

$$
\frac{C_{e}}{q e}=\frac{1}{X m} K L+\frac{C_{e}}{X m}
$$

where

$\mathrm{Ce}$ is equilibrium concentration, $q e$ is the amount of lead adsorbed at equilibrium, and

$\mathrm{X} m$ and $K L$ are Langmuir constants obtained by using the linearized Langmuir equation and Langmuir parameters. A comparison of linear plot of the Langmuir isotherm model and Freundlich model for adsorption of lead is presented in Figure 8 which represents a plot of $C e / q e(\mathrm{~g} / \mathrm{L})$ versus $C e(\mathrm{mg} / \mathrm{L})$ under various concentrations of lead sorption by biomass, biochar, and $\mathrm{TiO}_{2}$ nanocomposites. Most of the points on this graph were out of linearity. The obtained $\mathrm{R}^{2}$ values were 0.9016 for biomass, 0.5188 for biochar, and 0.6641 for nanocomposite for lead. The $\mathrm{R}^{2}$ values obtained with the Freundlich model were greater than those obtained with the Langmuir model, which suggests the nonapplicability of this model in interpreting sorption equilibrium data [57].
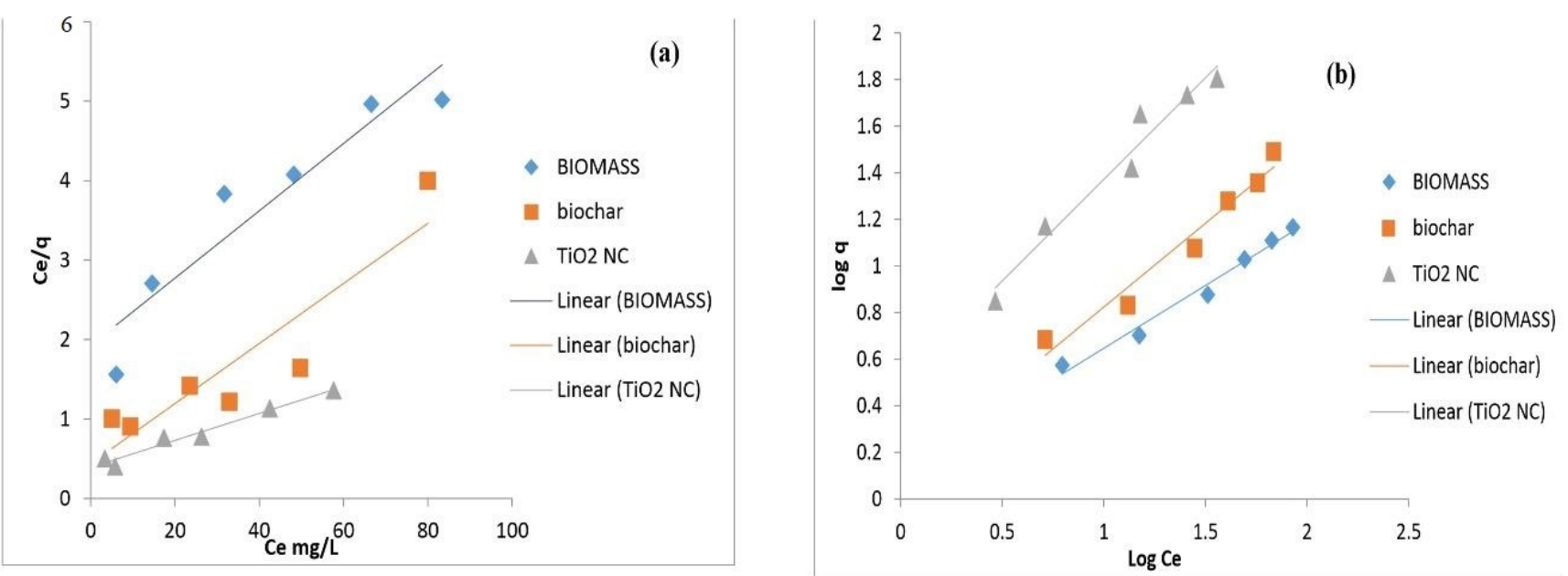

Figure 8. (a) Langmuir isotherm; (b) Freundlich isotherm for the adsorption of lead.

\subsection{Freundlich Isotherm}

The Freundlich isotherm equation is generally written as:

$$
Q e=K C e 1 / n
$$

It presumes monolayer adsorption distribution of active sites that are energetically heterogeneous, followed by interaction between biosorbents and adsorbed lead. The Freundlich isotherm equation is a mathematical expression that describes the adsorption of solute from an adsorbate solution to an adsorbent [58].

The linear equation for the Freundlich isotherm is

$$
\log q e=\log K f+(1 / n) \log C e
$$

where

qe $(\mathrm{mg} / \mathrm{g})$ is the quantity of lead adsorbed by specified amount of adsorbent at equilibrium, $\mathrm{Ce}(\mathrm{mg} / \mathrm{L})$ is the equilibrium concentration, $K f$ is the intercept constant obtained from the regression equation, and $1 / n=$ the slope constant obtained from the regression equation [59]. Compared to the Langmuir isotherm plot, this showed more linearity. The Freundlich model is better equipped to model lead sorption on the studied adsorbents than the Langmuir model.The value of $\mathrm{R}^{2}$ was near to unity in Freundlich model ( 0.9795 for biomass, 0.9592 for biochar, and 0.958 for $\mathrm{TiO}_{2}$ nanocomposite), which 
was a result of the higher correlation coefficient displayed by this model. The Freundlich isotherm was thus proven to be the best suited, and the equilibrium sorption information was well interpreted. Comparison of the values obtained Langmuir and Freundlich model is given in Table 3.

Table 3. Comparison of Langmuir and Freundlich Models.

\begin{tabular}{|c|c|c|c|c|c|c|c|c|c|}
\hline \multirow[b]{2}{*}{ Adsorbate } & \multirow[b]{2}{*}{ Adsorbents } & \multicolumn{2}{|c|}{ Langmuir Model } & \multicolumn{3}{|c|}{ Experimental Value } & \multicolumn{2}{|c|}{ Freundlich Model } & \multirow[b]{2}{*}{$\mathbf{R}^{2}$} \\
\hline & & $\begin{array}{c}X m \\
(\mathrm{mg} / \mathrm{g})\end{array}$ & $\begin{array}{c}K L \\
(\mathrm{~L} / \mathrm{mg})\end{array}$ & $\mathbf{R}^{2}$ & & $\begin{array}{c}q e \\
(\mathrm{mg} / \mathrm{g})\end{array}$ & $1 / n$ & $\begin{array}{c}K_{F} \\
(\mathrm{mg} / \mathrm{g})\end{array}$ & \\
\hline \multirow{3}{*}{ Lead } & Biomass & 20.96 & 0.02 & 0.90 & 14.66 & 7.84 & 0.53 & -2.22 & 0.97 \\
\hline & Biochar & 67.11 & 0.009 & 0.51 & 31.21 & 13.48 & 0.71 & -2.26 & 0.95 \\
\hline & $\mathrm{TiO}_{2} \mathrm{NC}$ & 200 & 0.007 & 0.66 & 63.85 & 47.72 & 0.87 & 0.69 & 0.95 \\
\hline
\end{tabular}

\section{Conclusions}

In the present research work, the adsorption efficiency of biomass, biochar, and biochar-based $\mathrm{TiO}_{2}$ nanocomposites for lead was compared. Among these, the synthesized novel nanocomposites proved very effective for the removal of heavy metals. In the present research, potato peel and banana peel were dried and then ground to make biomass. The prepared biomass was then pyrolyzed to make biochar. Leaves of Psidium guajava were utilized to prepare $\mathrm{TiO}_{2}$ nanoparticles by using titanium precursors. The prepared biochar was then sonicated with the $\mathrm{TiO}_{2}$ NPs to make nanocomposites for better adsorption of heavy metals. Several parameters, such as initial concentration of heavy metals, $\mathrm{pH}$, contact time, and dosage rate, were optimized. The percentage of removal of heavy metals was investigated. The maximum removal of lead was at $\mathrm{pH}$ 5. Lead removal decreased when lead concentration was increased, while it increased as dosage rate and contact time were increased. Uptake capacity of heavy metals from aqueous solution was in order of biomass $<$ biochar $<\mathrm{TiO}_{2}$ nanocomposites. Among them, the NCs were confirmed to have the maximum uptake capacity. The Freundlich model better explained the adsorption process of heavy metals as compared to the Langmuir model, as $\mathrm{R}^{2}$ for the Freundlich isotherm was higher than that for the Langmuir isotherm.

Author Contributions: Conceptualization, A.A.; methodology, A.A., R.N. and M.N.; validation, A.A., R.N., M.A., U.R. and M.N.; formal analysis, A.A., A.H., N.J. and Z.A. (Zeeshan Ashfaq); investigation, A.A., S.B. and M.A.; resources, N.J. and Z.A. (Zeeshan Ashfaq); data curation, Z.A. (Zeeshan Ashfaq) and Z.A. (Zubair Ahmed); writing-original draft preparation, A.A.; visualization, R.N.; supervision, A.A. and R.N.; funding acquisition, R.N., S.B., U.R. and A.H.; Project administration, R.N., U.R. and Z.A. (Zubair Ahmed) All authors have read and agreed to the published version of the manuscript.

Funding: Higher Education Commission of Pakistan, viz grant \#TDF-02-153.

Institutional Review Board Statement: Not applicable.

Informed Consent Statement: Not applicable.

Data Availability Statement: Not applicable.

Acknowledgments: The work was supported by the Technology Development Fund and Higher Education Commission of Pakistan, viz grant \#TDF-02-153. The authors would like to thank the TDF and HEC of Pakistan for their support.

Conflicts of Interest: Authors have no conflict of interest.

\section{References}

1. Azimi, A.; Azari, A.; Rezakazemi, M.; Ansarpour, M. Removal of heavy metals from industrial wastewaters: A review. Chem. BioEng. Rev. 2017, 4, 37-59. [CrossRef]

2. Kyzas, G.Z.; Bomis, G.; Kosheleva, R.I.; Efthimiadou, E.K.; Favvas, E.P.; Kostoglou, M.; Mitropoulos, A.C. Nanobubbles effect on heavy metal ions adsorption by activated carbon. Chem. Eng. J. 2019, 356, 91-97. [CrossRef] 
3. Dai, Q.H.; Bian, X.Y.; Li, R.; Jiang, C.B.; Ge, J.M.; Li, B.L.; Ou, J. Biosorption of lead(II) from aqueous solution by lactic acid bacteria. Water Sci. Technol. 2019, 79, 627-634. [CrossRef]

4. Davies, K.M.; Mercer, J.F.B.; Chen, N.; Double, K.L. Copper dyshomoeostasis in Parkinson's disease: Implications for pathogenesis and indications for novel therapeutics. Clin. Sci. 2016, 130, 565-574. [CrossRef]

5. Hashem, M.A.; Momen, M.A.; Hasan, M.; Nur-A-Tomal, M.S.; Sheikh, M.H.R. Chromium removal from tannery wastewater using Syzygium cumini bark adsorbent. Int. J. Environ. Sci. Technol. 2018, 16, 1395-1404. [CrossRef]

6. Crini, G.; Lichtfouse, E.; Wilson, L.D.; Morin-Crini, N. Conventional and non-conventional adsorbents for wastewater treatment. Environ. Chem. Lett. 2018, 17, 195-213. [CrossRef]

7. Wang, B.; Bai, Z.; Jiang, H.; Prinsen, P.; Luque, R.; Zhao, S.; Xuan, J. Selective heavy metal removal and water purification by microfluidically-generated chitosan microspheres: Characteristics, modeling and application. J. Hazard. Mater. 2019, 364, 192-205. [CrossRef] [PubMed]

8. Akhtar, K.; Akhtar, M.W.; Khalid, A.M. Removal and recovery of zirconium from its aqueous solution by Candida tropicalis. J. Hazard. Mater. 2008, 156, 108-117. [CrossRef]

9. Abdi, O.; Kazemi, M. A review study of biosorption of heavy metals and comparison between different biosorbents. J. Mater. Environ. Sci. 2015, 6, 1386-1399.

10. Oyewo, O.A.; Boshielo, A.; Adeniyi, A.; Onyango, M.S. Evaluation of the efficiency of nanoadsorbent derived from orange peels in the removal of cerium from aqueous solution. Part. Sci. Technol. 2021, 39, 43-51. [CrossRef]

11. Sun, J.; Li, X.; Ai, X.; Liu, J.; Yin, Y.; Huang, Y.; Zhou, H.; Huang, K. Efficient removal of cadmium from soil-washing effluents by garlic peel biosorbent. Environ. Sci. Pollut. Res. 2018, 25, 19001-19011. [CrossRef]

12. Pehlivan, E.; Altun, T. Biosorption of chromium (VI) ion from aqueous solutions using walnut, hazelnut and almond shell. $J$. Hazard. Mater. 2018, 155, 378-384. [CrossRef]

13. Çetinkaya, S.; Targan, Ş.; Tirtom, V.N. Comparative adsorption of Pb (II) and Cd (II) ions on chestnut shell in aqueous system. Chem. Ecol. 2018, 34, 640-654. [CrossRef]

14. Zheng, L.; Peng, D.; Meng, P. Corncob-supported aluminium-manganese binary oxide composite enhanced removal of cadmium ions. Colloids Surf. A Physicochem. Eng. Asp. 2019, 561, 109-119. [CrossRef]

15. Elias, M.M.C.; Ferreira, G.M.D.; Almeida, F.T.R.; MartinsRosa, N.C.; AlmeidaSilva, I.; GonçalvesFilgueiras, J.; Azevedo, E.R.; Silva, L.H.M.; Melo, T.M.S.; FrédéricGil, L.; et al. Synthesis and application of sugarcane bagasse cellulose mixed esters. Part I: Removal of $\mathrm{Co}^{2+}$ and $\mathrm{Ni}^{2+}$ from single spiked aqueous solutions in batch mode using. J. Colloid Interface Sci. 2019, 533, 678-691. [CrossRef] [PubMed]

16. Mohammed, T.; Ibrahim, R.; Naji, A. Experimental investigation and thermodynamic study of heavy metal removal from industrial wastewater using pomegranate peel. MATEC Web Conf. EDP Sci. 2018, 162, 05007. [CrossRef]

17. Chamarthy, S.; Seo, C.W.; Marshall, W.E. Adsorption of selected toxic metals by modified peanut shells. J. Chem. Technol. Biotechnol. 2001, 76, 593-597. [CrossRef]

18. El-Saharty, A.; Mahmoud, S.; Manjood, A.H.; Nassar, A.A.H.; Ahmed, A.M. Effect of apricot stone activated carbon adsorbent on the removal of toxic heavy metals ions from aqueous solutions. Int. J. Ecotoxicol. Ecobiol. 2018, 3, 51-62. [CrossRef]

19. Ahirwar Tech, B.M.; Scholar, R.; Kumar Sharma Professor, A.; Sharma Professor, S.; Bharti Ahirwar Tech, C.M.; Ahirwar, B.; Kumar Sharma, A.; Sharma, S. Impact Factor: 5.2 IJAR. IJAR 2017, 3, 459-462.

20. Sun, Y.; Yang, G.; Zhang, L. Biosorption of heavy metals: A case study using potato peel waste. Desalin. Water Treat. 2017, 83, 159-167. [CrossRef]

21. El-Azazy, M.; El-Shafie, A.; Issa, A.; Al-Sulaiti, M.; Al-Yafie, J.; Shomar, B.; Al-Saad, K. Potato peels as an adsorbent for heavy metals from aqueous solutions: Eco-structuring of a green adsorbent operating Plackett-Burman design. J. Chem. 2019. [CrossRef]

22. Ali, A. Removal of Mn (II) from water using chemically modified banana peels as efficient adsorbent. Environ. Nanotechnol. Monit. Manag. 2017, 7, 57-63. [CrossRef]

23. Mondal, N.K.; Samanta, A.; Chakraborty, S.; Shaikh, W.A. Enhanced chromium(VI) removal using banana peel dust: Isotherms, kinetics and thermodynamics study. Sustain. Water Resour. Manag. 2017, 4, 489-497. [CrossRef]

24. Sahmoune, M.N. Evaluation of thermodynamic parameters for adsorption of heavy metals by green adsorbents. Environ. Chem. Lett. 2019, 17, 697-704. [CrossRef]

25. Chen, Y.; Wang, H.; Zhao, W.; Huang, S. Four different kinds of peels as adsorbents for the removal of Cd (II) from aqueous solution: Kinetics, isotherm and mechanism. J. Taiwan Inst. Chem. Eng. 2018, 88, 146-151. [CrossRef]

26. Shrestha, S.L. A Comparative Study of Fe (II) Ion Adsorption onto Chemically Activated Banana Peel and Sawdust Bio-adsorbent. Int. J. Appl. Sci. Biotechnol. 2018, 6, 137-141. [CrossRef]

27. Sharma, H.K.; Sofi, I.R.; Wani, K.A. Low cost absorbents, techniques, and heavy metal removal efficiency. In Biostimulation Remediation Technologies for Groundwater Contaminants; IGI Global: Gwalior, India, 2018.

28. Regkouzas, P.; Diamadopoulos, E. Adsorption of selected organic micro-pollutants on sewage sludge biochar. Chemosphere 2019, 224, 840-851. [CrossRef] [PubMed]

29. Zhou, N.; Chen, H.; Xi, J.; Yao, D.; Zhou, Z.; Tian, Y.; Lu, X. Biochars with excellent Pb(II) adsorption property produced from fresh and dehydrated banana peels via hydrothermal carbonization. Bioresour. Technol. 2017, 232, 204-210. [CrossRef]

30. Yahia, I.S.; Shkir, M.; Keshk, S.M.A.S. Physicochemical properties of a nanocomposite (graphene oxide-hydroxyapatite-cellulose) immobilized by Ag nanoparticles for biomedical applications. Results Phys. 2020, 16, 102990. [CrossRef] 
31. Thostenson, E.T.; Li, C.; Chou, T.W. Nanocomposites in context. Compos. Sci. Technol. 2005, 65, 491-516. [CrossRef]

32. Youssef, A.M.; El-Naggar, M.E.; Malhat, F.M.; El Sharkawi, H.M. Efficient removal of pesticides and heavy metals from wastewater and the antimicrobial activity of f-MWCNTs/PVA nanocomposite film. J. Clean. Prod. 2019, 206, 315-325. [CrossRef]

33. Youssef, A.M.; El-Sayed, S.M. Bionanocomposites materials for food packaging applications: Concepts and future outlook. Carbohydr. Polym. 2018, 193, 19-27. [CrossRef]

34. Rehman, R.; Farooq, S.; Mahmud, T. Use of agro-waste Musa acuminata and Solanum tuberosum peels for economical sorptive removal of emerald green dye in ecofriendly way. J. Clean. Prod. 2019, 206, 819-826. [CrossRef]

35. Sakthivel, T.; Ramachandran, R.; Kirubakaran, K. Photocatalytic properties of copper-two dimensional graphitic carbon nitride hybrid film synthesized by pyrolysis method. J. Environ. Chem. Eng. 2018, 6, 2636-2642. [CrossRef]

36. Deshmukh, K.K.; Hase, G.J.; Gaje, T.R.; Phatangare, N.D.; Shilpa, G.; Ashwini, V. Titanium oxide nanoparticles and degradation of dye by nanoparticles. Int. J. Mater. Sci. 2018, 13, 23-30.

37. Dey, A.; Nangare, V.; More, P.V.; Khan, M.A.S.; Khanna, P.K.; Sikder, A.K.; Chattopadhyay, S. A graphene titanium dioxide nanocomposite (GTNC): One pot green synthesis and its application in a solid rocket propellant. RSC Adv. 2015, 5, 63777-63785. [CrossRef]

38. Chougala, L.S.; Yatnatti, M.S.; Linganagoudar, R.K.; Kamble, R.R.; Kadadevarmath, J.S. A simple approach on synthesis of TiO 2 nanoparticles and its application in dye sensitized solar cells. J. Nano Electron. Phys. 2017, 9. [CrossRef]

39. Liang, S.; Han, Y.; Wei, L.; McDonald, A.G. Production and characterization of bio-oil and bio-char from pyrolysis of potato peel wastes. Biomass Convers. Biorefin. 2015, 5, 237-246. [CrossRef]

40. Thamaphat, K.; Limsuwan, P.; Ngotawornchai, B. Phase Characterization of $\mathrm{TiO}_{2}$ Powder by XRD and TEM. Nat. Sci. 2008, 42, 357-361.

41. Subhapriya, S.; Gomathipriya, P. Green synthesis of titanium dioxide $\left(\mathrm{TiO}_{2}\right)$ nanoparticles by Trigonella foenum-graecum extract and its antimicrobial properties. Microb. Pathog. 2018, 116, 215-220. [CrossRef]

42. Ali, A.; Saeed, K.; Mabood, F. Removal of chromium (VI) from aqueous medium using chemically modified banana peels as efficient low-cost adsorbent. Alex. Eng. J. 2016, 55, 2933-2942. [CrossRef]

43. Adebowale, K.O.; Unuabonah, I.E.; Olu-Owolabi, B.I. The effect of some operating variables on the adsorption of lead and cadmium ions on kaolinite clay. J. Hazard. Mater. 2006, 134, 130-139. [CrossRef] [PubMed]

44. Bueno, B.Y.M.; Torem, M.L.; Molina, F.; Mesquita, L.M.S. de Biosorption of lead(II), chromium(III) and copper(II) by R. opacus: Equilibrium and kinetic studies. Miner. Eng. 2008, 1, 65-75. [CrossRef]

45. Azouaou, N.; Sadaoui, Z.; Mokaddem, H. Removal of cadmium from aqueous solution by adsorption on vegetable wastes. J. Appl. Sci. 2008, 8, 4638-4643. [CrossRef]

46. Osman1a, H.E.; Badwy, R.K.; Ahmad, H.F. Usage of some agricultural by-products in the removal of some heavy metals from industrial wastewater. J. Phytol. 2010, 2, 51-62.

47. Jacques, R.A.; Lima, E.C.; Dias, S.L.P.; Mazzocato, A.C.; Pavan, F.A. Yellow passion-fruit shell as biosorbent to remove Cr (III) and $\mathrm{Pb}$ (II) from aqueous solution. Sep. Purif. Technol. 2007, 57, 193-198. [CrossRef]

48. Aksu, Z.; İşoğlu, İ.A. Removal of copper (II) ions from aqueous solution by biosorption onto agricultural waste sugar beet pulp. Process. Biochem. 2005, 40, 3031-3044. [CrossRef]

49. Pehlivan, E.; Cetin, S.; Yanık, B.H. Equilibrium studies for the sorption of zinc and copper from aqueous solutions using sugar beet pulp and fly ash. J. Hazard. Mater. 2006, 135, 193-199. [CrossRef]

50. Eslamzadeh, T.; Nasernezhad, B.; Esmaeil, B.M. Removal of heavy metals from aqeous solution by carrot residues. Iran. J. Sci. Technol. Trans. A-Sci. 2004, 28, 161-167.

51. Schiewer, S.; Patil, S.B. Pectin-rich fruit wastes as biosorbents for heavy metal removal: Equilibrium and kinetics. Bioresour. Technol. 2008, 99, 1896-1903. [CrossRef]

52. Arslanoglu, H.; Altundogan, H.S.; Tumen, F. Preparation of cation exchanger from lemon and sorption of divalent heavy metals. Bioresour. Technol. 2008, 99, 2699-2705. [CrossRef]

53. Ho, Y.S.; Ng, J.C.Y.; McKay, G. Kinetics of pollutant sorption by biosorbents: Review. Sep. Purif. Methods 2000, $29,189-232$. [CrossRef]

54. Sari, A.; Tuzen, M.; Citak, D.; Soylak, M. Equilibrium, kinetic and thermodynamic studies of adsorption of Pb(II) from aqueous solution onto Turkish kaolinite clay. J. Hazard. Mater. 2007, 149, 283-291. [CrossRef] [PubMed]

55. Gouanvé, F.; Marais, S.; Bessadok, A.; Langevin, D.; Morvan, C.; Métayer, M. Study of water sorption in modified flax fibers. J. Appl. Polym. Sci. 2006, 101, 4281-4289. [CrossRef]

56. Huang, Y.; Shih, M. Effect of linearized expressions of Langmuir equations on the prediction of the adsorption of methylene blue on rice husk. Int. J. Sci. Res. Publ. 2016, 6, 549-554.

57. Chung, H.K.; Kim, W.H.; Park, J.; Cho, J.; Jeong, T.Y.; Park, P.K. Application of Langmuir and Freundlich isotherms to predict adsorbate removal efficiency or required amount of adsorbent. J. Ind. Eng. Chem. 2015, 28, 241-246. [CrossRef]

58. Ayawei, N.; Ebelegi, A.N.; Wankasi, D. Modelling and Interpretation of Adsorption Isotherms. J. Chem. 2017, $2017,3039817$. [CrossRef]

59. Kim, H.; Kang, S.O.; Park, S.; Park, H.S. Adsorption isotherms and kinetics of cationic and anionic dyes on three-dimensional reduced graphene oxide macrostructure. J. Ind. Eng. Chem. 2015, 21, 1191-1196. [CrossRef] 